\title{
Desinfecção com dióxido de cloro
}

\author{
C R ISTINA MARIA MARTINS A L M I D A*
}

O dióxido de cloro $\left(\mathrm{ClO}_{2}\right)$ tem vindo a ser utilizado na pré-oxidação e desinfecção da água para consumo humano, em alternativa ao cloro $\left(\mathrm{Cl}_{2}\right)$. Pretende-se com este trabaIho descrever as vantagens e desvantagens associadas à sua utilização. Com este objectivo, organizou-se a informação, nomeadamente no que se refere às propriedades físico-químicas, tecnologias de produção (eficiência dos processos e avaliação da pureza do dióxido de cloro produzido), eficácia da desinfecção e metodologias de monitorização do dióxido de cloro e dos respectivos subprodutos clorados.

\section{Introdução}

A qualidade da água de consumo humano pode afectar a saúde ou o bem-estar de uma comunidade de várias formas. A contaminação química pode estar relacionada com quantidades vestigiárias de substâncias (especialmente substâncias orgânicas) mas deve ser avaliada em relação a outros riscos para a saúde associados à água de consumo, nomeadamente, a transmissão de doenças (de origem bacteriana, vírica ou parasitária).

Os surtos epidémicos a partir da água distribuída são ainda uma realidade, mesmo em países onde se trata a água com um nível aceitável de qualidade. Na maioria dos casos a razão deve-se a uma falha do processo de desinfecção ou à ausência deste processo.

A desinfecção da água potável é essencial para evitar a transmissão de doenças, tanto nos países em vias de desenvolvimento como nos países industrializados. No entanto, os potenciais riscos dos subprodutos da desinfecção não podem ser ignorados, ainda que seja necessário investigar mais em pormenor, não só, os seus efeitos como também a sua eliminação da água,

*Faculdade de Farmácia da Universidade de Lisboa, Laboratório de Hidrologia e Analises Hidrológicas

Av. das Forças Armadas, 1649-083 Lisboa sem nunca comprometer a desinfecção completa da água para consumo humano. Em cada abastecimento há que procurar o ponto óptimo entre o balanço a longo prazo dos riscos para a saúde procedentes dos subprodutos da desinfecção com os riscos a curto prazo procedentes da possível presença de microrganismos patogénicos na água.

Na maioria dos países a cloração ainda é o método de desinfecção mais utilizado, e em nenhum caso o seu papel é discutido. No entanto, devido à problemática dos subprodutos clorados, a maioria dos países, principalmente os do norte e centro da Europa e os Estados Unidos da América, têm substituído o cloro por ozono ou dióxido de cloro na fase de pré-oxidação, de forma a diminuir o tipo e quantidade de subprodutos clorados formados. 0 cloro é apenas utilizado na fase terminal do tratamento de água, isto é, na desinfecção, de forma a garantir uma acção desinfectante residual na rede de distribuição.

Dos vários subprodutos da cloração, os que se formam em maior quantidade e que têm sido alvo de um maior número de estudos são os trihalometanos. Os trihalometanos que ocorrem mais frequentemente nas águas para beber são o clorofórmio, bromodiclorometano, dibromoclorometano e o bromofórmio, os quais se encontram presentes frequentemente em concentrações entre 10 e $100 \mu \mathrm{g} / \mathrm{L}$.

Nestes últimos anos têm-se criado leis que regulamentam os limites de trihalometanos numa água para beber. Estas regulamentações surgem como consequência do conhecimento da presença e origem dos trihalometanos na água, assim como das investigações epidemiológicas e toxicológicas que confirmam o seu potencial risco para a saúde pública. Um exemplo disso é a Directiva Comunitária 98/83/CE de 3 de Novembro destinada à água para consumo humano e transposta para o direito nacional através do DL 243/01 de 5 de Setembro. Este decreto-lei exige que a soma da concentração em trihalometanos seja igual ou inferior a $150 \mu \mathrm{g} / \mathrm{L}$ até 2008 e que a partir de 2008 este valor seja inferior ou igual a $100 \mu \mathrm{g} / \mathrm{L}$. Por outro lado, este decreto-lei também inclui pela primeira vez a determinação do bromato no controlo de inspecção. Devido à toxicidade dos bromatos, o referido decreto-lei estabelece o valor paramétrico de $10 \mu \mathrm{g} / \mathrm{L}$ na água para consumo humano, de forma a assegurar a protecção da saúde humana.

Em consequência desta legislação, as estações de tratamento de água destinada ao consumo humano tiveram que avaliar as suas práticas de desinfecção e de tratamento da água, e é de pre- 
ver que algumas técnicas de tratamento serão incrementadas, nomeadamente as que conduzem a uma diminuição dos bromatos e dos subprodutos clorados, nomeadamente, os trihalometanos. A fase do tratamento onde possivelmente haverá mais modificações será aquela onde ocorre a maior taxa de formação de subprodutos clorados e de bromatos, isto é, na pré-oxidação. Nesta fase, um dos processos alternativos será a substituição do cloro por um oxidante/ desinfectante alternativo. Este trabalho pretende abordar uma destas práticas alternativas de desinfecção, nomeadamente, a utilização do dióxido de cloro.

A primeira utilização do dióxido de cloro remonta ao início do século XX, quando ele foi utilizado na desinfecção de uma estância termal em Ostende (Bélgica). Desde então, tem sido reconhecido como um poderoso desinfectante da água e na década de 1950 foi introduzido de forma gradual na desinfecção da água para consumo humano, em virtude de não originar alterações organolépticas na água tão significativas quanto as provocadas pelo cloro. Numa Estação de Tratamento de Água (ETA) o dióxido de cloro tem vindo a ser usado quer na pré-oxidação, quer na desinfecção final. Em Portugal alguns dos sistemas multi-municipais de tratamento de água já começaram a utilizar na pré-oxidação o dióxido de cloro, como por exemplo, a ETA de Vila Nova de Santo André, a ETA das Fontainhas, a ETA do Roxo (concelho de Aljustrel), a ETA de Nossa Senhora do Desterro e as Águas do Douro e Paiva.

O dióxido de cloro pode ser usado como agente oxidante e também como agente desinfectante. A sua aplicação tem, porém, levantado algumas dúvidas, em grande parte relacionadas com o facto de, durante a sua produção e após o contacto com a água, dar origem a subprodutos, nomeadamente, cloritos e cloratos, os quais podem ser nocivos para a saúde humana [1,2].

A acção do dióxido de cloro como agente desinfectante é particularmente eficaz na erradicação da Giardia e de um elevado número de vírus. Este reagente tem sido reconhecido como o mais eficaz na inactivação de bactérias e do Cryptospo- ridium num intervalo grande de valores de $\mathrm{pH}$, quando comparado com os valores obtidos com o cloro gasoso. No entanto, as doses de dióxido de cloro necessárias para a acção virucida podem ser de alguma forma condicionadas devido à formação excessiva do ião clorito. Nas águas superficiais, a capacidade do dióxido de cloro para inactivar a maioria dos vírus presentes neste tipo de águas é comparável à do cloro [3].

A preocupação crescente com os protozoários, nomeadamente, com a Giardia e o Cryptosporidium, deve-se ao facto de serem parasitas perigosos do ponto de vista de saúde pública, pois podem provocar disenteria e gastroenterites e porque nas doses usuais de cloro usadas na desinfecção estes não são destruídos ou inactivados.

O dióxido de cloro também permite controlar a formação dos compostos responsáveis pelo sabor e odor na água, tal como os clorofenóis, e oxida de forma eficaz os respectivos compostos precursores. É também particularmente eficaz na eliminação do ferro e do manganês que se encontram dissolvidos na água, sobretudo em águas subterrâneas.

Ao contrário do cloro gasoso, o dióxido de cloro não reage com a matéria orgânica presente na água, nem com diversos compostos orgânicos e não origina subprodutos clorados, como os trihalometanos (THM). Por esta razão, o dióxido de cloro pode ser uma boa alternativa ao cloro gasoso quando se pretende diminuir o nível de trihalometanos numa água para consumo humano [4].

Outra vantagem do dióxido de cloro é não oxidar o ião brometo a bromato ou a ácido hipobromoso, compostos que podem reagir com a matéria orgânica originando subprodutos bromados.

Podem ser atribuídas ao dióxido de cloro várias vantagens e desvantagens. No entanto, devido à grande variação na dimensão dos sistemas de distribuição, na qualidade da água e na dosagem aplicada, algumas destas vantagens e desvantagens não se aplicam a um determinado sistema de distribuição. Regra geral, são atribuídas ao dióxido de cloro as seguintes vantagens $[3,5,6]$ :
- O dióxido de cloro é mais eficaz que o cloro e que as cloraminas na inactivação dos vírus e dos protozoários, como o Cryptosporidium e a Giardia.

- O dióxido de cloro oxida o ferro, o manganês e os sulfuretos.

- O dióxido de cloro pode facilitar o processo de clarificação.

- O sabor e cheiro resultantes da degradação das algas e da matéria vegetal, assim como a devida aos compostos fenólicos, são controlados através da utilização do dióxido de cloro.

- Sob condições controladas de produção (i.e., sem excesso de cloro), não se formam os subprodutos da desinfecção halogenados (por exemplo, trihalometanos).

- A produção do dióxido de cloro é fácil.

- As propriedades biocidas não são influenciadas pelo $\mathrm{pH}$ da água.

- O dióxido de cloro garante uma acção desinfectante residual.

Por outro lado, são-Ihe atribuídas as seguintes desvantagens:

- O dióxido de cloro forma subprodutos da desinfecção específicos, nomeadamente, cloritos e cloratos.

- A eficiência do gerador do dióxido de cloro e a dificuldade na sua optimização podem conduzir a um excesso de cloro, o qual pode ser aplicado à água e formar subprodutos da desinfecção halogenados.

- Os custos associados com a formação, a amostragem e os testes de monitorização do clorito e clorato são elevados.

- O dióxido de cloro não pode ser comprimido ou armazenado comercialmente como um gás porque é explosivo sob pressão. Desta forma, ele nunca é expedido ou comercializado na forma gasosa, devendo ser gerado in 10 co.

- O custo da sua produção é elevado, quer em termos de instalação, quer de pessoal e manutenção.

- O dióxido de cloro é fotossensível. 
- Em alguns sistemas pode dar origem à formação de cheiros desagradáveis.

\section{Propriedades Físico-Químicas}

A $25^{\circ} \mathrm{C}$ e 1 bar, o $\mathrm{ClO}_{2}$ puro é um gás. Em solução, o $\mathrm{ClO}_{2}$ é fotossensível e decompõe-se através dos radicais livres $\left(\mathrm{ClO}_{2} \cdot \text { e } \mathrm{ClO}\right)^{\bullet}$ em ião clorato $\left(\mathrm{ClO}_{3}^{-}\right)$e cloreto $\left(\mathrm{Cl}^{-}\right)$. Dado o seu elevado grau de instabilidade, o dióxido de cloro deve ser produzido no local em que vai ser utilizado, sendo produzido de acordo com a necessidade instantânea do composto.

A Tabela 1 apresenta uma lista das propriedades físicas gerais do dióxido de cloro [5].

Nas soluções aquosas de dióxido de cloro existem normalmente várias espécies de cloro, as quais são subprodutos da reacção do dióxido de cloro ou precursores inerentes à sua produção. A Tabela 2 apresenta as várias espécies de cloro que podem aparecer nos geradores de dióxido de cloro. Além destas espécies cloradas, há ainda a considerar os radicais $\mathrm{ClO}_{2}{ }^{\bullet}$ e $\mathrm{ClO}{ }^{\bullet}$.

Uma das propriedades físicas mais importantes do dióxido de cloro é a sua elevada solubilidade em água, especialmente em água fria. Contrariamente à hidrólise do cloro gasoso na água, o dióxido de cloro não se hidrolisa de forma extensiva na água, permanecendo em solução na sua forma molecular. É aproximadamente 10 vezes mais solúvel que o cloro (acima de $11^{\circ} \mathrm{C}$ ), extremamente volátil e pode ser removido das soluções aquosas diluídas por arejamento suave ou recarbonatação com dióxido de carbono (por exemplo, amaciamento ou eliminação da dureza). Acima dos $11-12^{\circ} \mathrm{C}$, o $\mathrm{ClO}_{2}$ encontra-se no estado gasoso (Tabela 1). Esta característica pode influenciar a eficácia do dióxido de cloro quando se preparam vários lotes de solução para serem injectados em determinados pontos da canalização. Outra dificuldade é a monitorização do dióxido de cloro na água, não só devido à elevada volatilidade do composto, mas também devido à presença de outros interferentes (nomeadamente, de outros compostos clorados).

Tabela 1 Estrutura molecular e propriedades físicas do dióxido de cloro

\begin{tabular}{|c|c|}
\hline \multicolumn{2}{|c|}{ Dióxido de cloro o ôn } \\
\hline Massa molecular & $67,45 \mathrm{~g} / \mathrm{mol}$ \\
\hline Ponto de fusão & $-59^{\circ} \mathrm{C}\left(-75^{\circ} \mathrm{F}\right)$ \\
\hline Ponto de ebulição & $11^{\circ} \mathrm{C}\left(51^{\circ} \mathrm{F}\right)$ \\
\hline Solubilidade, $25^{\circ} \mathrm{C}(34,5 \mathrm{~mm} \mathrm{Hg})$ & $\sim 3 \mathrm{~g} / \mathrm{L}$ \\
\hline Coeficiente de partição, $35^{\circ} \mathrm{C}\left(95^{\circ} \mathrm{F}\right)$ & 21,5 \\
\hline Absortividade molar, $360 \mathrm{~nm}$ & $1225-1250 \mathrm{~cm}^{-1} \mathrm{M}^{-1}$ \\
\hline
\end{tabular}

Tabela 2 Estados de oxidação do cloro [5]

\begin{tabular}{ccc}
\hline Estado oxidação & Espécies & Fórmula \\
\hline+7 & lão perclorato & $\mathrm{ClO}_{4}^{-}$ \\
\hline+5 & lão clorato & $\mathrm{ClO}_{3}^{-}$ \\
\hline+4 & Dióxido de cloro & $\mathrm{ClO}_{2}$ \\
\hline+3 & lão clorito & $\mathrm{ClO}_{2}^{-}$ \\
\cline { 2 - 3 } & Ácido cloroso & $\mathrm{HClO}_{2}$ \\
\hline+1 & lão hipoclorito & $\mathrm{OCl}^{-}$ \\
\hline 0 & Ácido hipocloroso & $\mathrm{HOCl}^{-}$ \\
\hline-1 & Cloro & $\mathrm{Cl}_{2}$ \\
\hline
\end{tabular}

O dióxido de cloro é um composto neutro, em que o cloro está no estado de oxidação +4 (Tabela 2). A sua acção desinfectante é em termos químicos uma oxidação, no entanto, o dióxido de cloro não actua como agente de cloração. Em elevadas concentrações, reage dade, indicando que o ião clorito existe como espécie dominante na água de consumo humano.

Apresenta-se de seguida, o potencial de oxidação-redução das principais reacções químicas envolvidas:

$$
\begin{array}{ll}
\mathrm{ClO}_{2} \text { (aq) }+e^{-} \rightleftarrows \mathrm{ClO}_{2}^{-} & E^{\circ}=0,954 \mathrm{~V} \\
\mathrm{ClO}_{2}^{-}+2 \mathrm{H}_{2} \mathrm{O}+4 \mathrm{e}^{-} \rightleftarrows \mathrm{Cl}^{-}+4 \mathrm{OH}^{-} & \mathrm{E}^{\circ}=0,76 \mathrm{~V} \\
\mathrm{ClO}_{3}{ }^{-}+\mathrm{H}_{2} \mathrm{O}+2 e^{-} \rightleftarrows \mathrm{ClO}_{2}{ }^{-}+2 \mathrm{OH}^{-} & \mathrm{E}^{\circ}=0,33 \mathrm{~V} \\
\mathrm{ClO}_{3}{ }^{-}+2 \mathrm{H}^{+}+e^{-} \rightleftarrows \mathrm{ClO}_{2}+\mathrm{H}_{2} \mathrm{O} & \mathrm{E}^{\circ}=1,152 \mathrm{~V}
\end{array}
$$

violentamente com os agentes redutores presentes no meio. Contudo, o dióxido de cloro é estável em soluções aquosas diluídas quando armazenado num contentor fechado e ao abrigo da luz [7].

A função do dióxido de cloro como agente oxidante altamente selectivo deve-se ao seu mecanismo único de transferência de um electrão $\left(e^{-}\right)$, sendo reduzido a ião clorito $\left(\mathrm{ClO}_{2}^{-}\right)$. O pKa do ião clorito, em equilíbrio com o ácido cloroso, é extremamente baixo a $\mathrm{pH}$ 1,8 . Isto é completamente diferente do par em equilíbrio ácido hipocloroso/ião hipoclorito perto da zona de neutrali-
$\mathrm{Na}$ água de consumo humano, o ião clorito $\left(\mathrm{ClO}_{2}^{-}\right)$é o subproduto predominante, com 50 a $70 \%$ proveniente do dióxido de cloro e 30\% proveniente do clorato $\left(\mathrm{ClO}_{3}^{-}\right)$e cloreto $\left(\mathrm{Cl}^{-}\right)$.

O conhecimento das propriedades e reacções do dióxido de cloro, assim como os avanços nas tecnologias de produção e purificação do dióxido de cloro, têm permitido a utilização de um produto mais puro no tratamento da água para consumo humano, isto é, tem aumentado a eficiência de produção do dióxido de cloro, minimizando o tipo e número de subprodutos formados [6]. 


\section{Produção de Dióxido de Cloro}

\subsection{Métodos}

Para o tratamento da água, os geradores comerciais de dióxido de cloro podem, de uma forma simples, ser classificados em três grupos: os sistemas baseados na oxidação do ião clorito, os sistemas baseados na redução do ião clorato e os sistemas electroquímicos.

Apresenta-se na Tabela 3 um resumo das várias tecnologias de produção do dióxido de cloro, verificando-se que a produção de dióxido de cloro, quer a partir do clorito (processo por oxidação), quer a partir do clorato (processo por redução), pode ser complicada. 0 processo químico envolve precursores (e.g., $\mathrm{ClO}_{2}^{-}$líquido ou $\mathrm{ClO}_{3}^{-}$na forma sólida), agentes oxidantes ou redutores (e.g., $\mathrm{Cl}_{2}, \mathrm{H}_{2} \mathrm{O}_{2}$ ), ácidos e células electroquímicas e vários processos gasosos de mistura e extracção. Em qualquer um dos casos, o produto final contém $\mathrm{ClO}_{2}$.

Para um grande número das tecnologias usuais de produção, são geradas soluções de dióxido de cloro entre 0,1 a 0,5\% para o tratamento da água para consumo humano.

\subsubsection{Produção baseada na oxidação do ião clorito [5]}

Nas estações de tratamento de água, a oxidação do ião clorito é o método mais utilizado para a produção de dióxido de cloro. Um dos primeiros geradores deste tipo utilizava ácido para converter o ião clorito em dióxido de cloro. 0 processo pode ser descrito através da equação seguinte:

$5 \mathrm{ClO}_{2}^{-}+4 \mathrm{H}^{+} \rightarrow 4 \mathrm{ClO}_{2}+\mathrm{Cl}^{-}+2 \mathrm{H}_{2} \mathrm{O}$

A estequiometria desta reacção permite verificar que $20 \%$ do reagente de partida não origina dióxido de cloro. Isto significa que o ião clorito não é consumido na totalidade, isto é, apenas $80 \%$ é convertido em $\mathrm{ClO}_{2}$. Neste caso, uma taxa elevada de conversão não resulta num elevado rendimento. Este exemplo permite demonstrar que o consumo do ião clorito não deve ser usado como base para o cálculo do rendimento.

Tabela 3 Tecnologias de formação de dióxido de cloro [5]

\begin{tabular}{ll}
\hline Processo químico & Observaçães \\
\hline $\mathrm{ClO}_{2} / / \mathrm{Cl}_{2}$ & Solução de ião clorito/cloro gasoso; \\
\hline $\mathrm{ClO}_{2}-/ \mathrm{H}^{+}$ & $\begin{array}{l}\text { Solução de ião clorito/cloro aquoso; } \\
\text { Clorito sólido/cloro gasoso }\end{array}$ \\
\hline $\mathrm{ClO}_{3}-/ \mathrm{H}^{+} /$Agente redutor & Activação ácida \\
\hline $\mathrm{ClO}_{3}-/ \mathrm{H}_{2} \mathrm{SO}_{4} / \mathrm{H}_{2} \mathrm{O}_{2}$ & Produção em grande escala \\
\hline Electroquímico $\left(\mathrm{ClO}_{2}^{-}\right)$ & Produção em pequena escala \\
\hline
\end{tabular}

Normalmente, o dióxido de cloro é produzido a partir da reacção do ião clorito com o cloro ou com o ácido hipocloroso.

$2 \mathrm{ClO}_{2}{ }^{-}+\mathrm{Cl}_{2}(\mathrm{~g}) \rightarrow 2 \mathrm{ClO}_{2}+2 \mathrm{Cl}^{-}$

$2 \mathrm{ClO}_{2}^{-}+\mathrm{HOCl} \rightarrow 2 \mathrm{ClO}_{2}+\mathrm{Cl}^{-}+\mathrm{OH}^{-}$

As equações das reacções $1 \mathrm{a}, 1 \mathrm{~b}$ e 1c explicam como é que os geradores podem ser diferentes, mesmo quando o precursor é o mesmo. Também indicam que alguns geradores requerem o controlo de pH e outros não são dependentes deste factor. Na maioria dos geradores, a reacção de produção de dióxido de cloro envolve mais de um passo, isto é, há mais que uma reacção envolvida. Por exemplo, a formação e acção do ácido hipocloroso como intermediário (resultante da reacção do cloro com a água) mascara frequentemente todas as reacções inerentes à produção do dióxido de cloro. Por outro lado, a equação geral da reacção do ião clorito com o $\mathrm{Cl}_{2}$ não mostra a importância da espécie intermediária, $\mathrm{Cl}_{2} \mathrm{O}_{2}$.

$\mathrm{ClO}_{2}^{-}+\mathrm{Cl}_{2} \rightarrow\left[\mathrm{Cl}_{2} \mathrm{O}_{2}\right]+\mathrm{Cl}^{-}$

Para concentrações muito elevadas de reagente, a espécie intermediária forma-se muito rapidamente.

$2\left[\mathrm{Cl}_{2} \mathrm{O}_{2}\right] \rightarrow 2 \mathrm{ClO}_{2}+\mathrm{Cl}_{2}$

$\left[\mathrm{Cl}_{2} \mathrm{O}_{2}\right]+\mathrm{ClO}_{2}^{-} \rightarrow 2 \mathrm{ClO}_{2}+\mathrm{Cl}^{-}$

Para baixas concentrações iniciais de reagente, forma-se primeiro o ião clorato.
$\left[\mathrm{Cl}_{2} \mathrm{O}_{2}\right]+\mathrm{H}_{2} \mathrm{O} \rightarrow \mathrm{ClO}_{3}{ }^{-}+\mathrm{Cl}^{-}+2 \mathrm{H}^{+}$

As equações seguintes referem-se às reacções indesejáveis que levam à formação de ião clorato.

$\mathrm{ClO}_{2}{ }^{-}+\mathrm{HOCl} \rightarrow \mathrm{ClO}_{3}{ }^{-}+\mathrm{Cl}^{-}+\mathrm{H}^{+}$

$\mathrm{ClO}_{2}^{-}+\mathrm{Cl}_{2}+\mathrm{H}_{2} \mathrm{O} \rightarrow \mathrm{ClO}_{3}^{-}+2 \mathrm{Cl}^{-}+2 \mathrm{H}^{+}$

No mercado também existem sistemas que utilizam o ião clorito, não na forma aquosa, mas na forma sólida. Este sistema foi desenvolvido para minimizar a presença de $\mathrm{Cl}_{2}$ no dióxido de cloro formado. Em sistemas optimizados, o teor de $\mathrm{Cl}_{2}$ no produto final é inferior a $1 \%$. Este sistema consiste num leito cheio de clorito de sódio embebido em substâncias estabilizantes e inertes. o cloro $\left(\mathrm{Cl}_{2}\right)$ humidificado e diluído passa através deste leito e reage com o ião clorito. Como o $\mathrm{Cl}_{2}$ e o ar estão a passar continuamente sobre o leito sólido, o dióxido de cloro é retirado à medida que se forma e transportado para um tanque de armazenamento.

\subsubsection{Produção baseada na redução do ião clorato}

Desde 1999 têm sido introduzidos geradores que utilizam o clorato de sódio $\left(\mathrm{NaClO}_{3}\right)$ como agente precursor, o qual é reduzido por uma mistura de água oxigenada concentrada $\left(\mathrm{H}_{2} \mathrm{O}_{2}\right)$ e ácido sulfúrico concentrado $\left(\mathrm{H}_{2} \mathrm{SO}_{4}\right)$. Estes geradores foram utilizados inicialmente nas indústrias de pasta de papel (branqueamento) e só posteriormente começaram a ser utilizados nas estações municipais de tratamento de água $[5,8]$. 
Estes sistemas usam $\mathrm{H}_{2} \mathrm{O}_{2}$ e $\mathrm{H}_{2} \mathrm{SO}_{4}$ em excesso para produzir dióxido de cloro, de acordo com as seguintes reacções:

$$
\begin{aligned}
& 2 \mathrm{ClO}_{3}{ }^{-}+\mathrm{H}_{2} \mathrm{SO}_{4}+\mathrm{H}_{2} \mathrm{O}_{2} \rightarrow \\
& \quad \rightarrow 2 \mathrm{ClO}_{2}+\mathrm{O}_{2}+\mathrm{SO}_{4}^{2-}+2 \mathrm{H}_{2} \mathrm{O}
\end{aligned}
$$

A optimização do processo de produção de dióxido de cloro requer um excesso de ácido para a conversão eficaz do $\mathrm{ClO}_{3}{ }^{-} \rightarrow \mathrm{ClO}_{2}$. A razão $\mathrm{H}_{2} \mathrm{O}_{2} / \mathrm{H}_{2} \mathrm{SO}_{4}$ é muito importante. As condições ideais para a máxima produção de dióxido de cloro não são necessariamente as condições que minimizam a formação de subprodutos. Em condições muito acídicas, especialmente com $\mathrm{H}_{2} \mathrm{SO}_{4}$, O clorato pode ser convertido em ião perclorato [5]:

$8 \mathrm{HClO}_{3} \rightarrow 4 \mathrm{HClO}_{4}+3 \mathrm{O}_{2}+2 \mathrm{H}_{2} \mathrm{O}+2 \mathrm{Cl}_{2}$

Por outro lado, as soluções comerciais de clorato de sódio $\left(\mathrm{NaClO}_{3}\right)$ apresentam ião perclorato, o qual pode passar para o tanque de armazenamento durante a produção do dióxido de cloro.

Podemos constatar que um gerador deste tipo, mas de menor dimensão, é potencialmente aplicável em estações de tratamento da água para consumo humano, com a finalidade de diminuir os custos associados à produção de dióxido de cloro. No entanto, os requisitos inerentes a uma água de consumo humano, a presença de $\mathrm{H}_{2} \mathrm{O}_{2}$ no efluente do gerador (não recomendado como desinfectante), o aumento da acidez (controlo da corrosão) e a formação de $\mathrm{ClO}_{4}^{-}$(risco potencial para a saúde) têm impedido a aceitação deste procedimento para a produção de dióxido de cloro [5].

\subsubsection{Sistemas electroquímicos}

Há vários anos que existem no mercado sistemas electroquímicos para a produção de dióxido de cloro. Conceptualmente, estes geradores são muito simples.

Electrólise directa $[5,6]$ :

$2 \mathrm{ClO}_{2}^{-}+2 \mathrm{H}_{2} \mathrm{O} \rightarrow 2 \mathrm{ClO}_{2}+2 \mathrm{OH}^{-}+\mathrm{H}_{2}$

É introduzida na célula electroquímica a solução de $\mathrm{NaClO}_{2}$. No ânodo ocorre a electrólise directa do $\mathrm{ClO}_{2}$ - para formar $\mathrm{ClO}_{2}$. No cátodo, é produzido hidróxido de sódio e hidrogénio. Para evitar a posterior oxidação do $\mathrm{ClO}_{2}$ a ião clorato e possivelmente a ião perclorato, o dióxido de cloro é extraído do ânodo.

Outro método electroquímico de produção do dióxido de cloro inclui a produção electroquímica de ácido ou de $\mathrm{Cl}_{2}$ como um meio de abastecimento de um dos precursores químicos à célula.

Electrólise da água:

$2 \mathrm{H}_{2} \mathrm{O} \rightarrow 4 \mathrm{H}^{+}+\mathrm{O}_{2}+4 e^{-}$

$5 \mathrm{ClO}_{2}^{-}+4 \mathrm{H}^{+} \rightarrow 4 \mathrm{ClO}_{2}+\mathrm{Cl}^{-}+2 \mathrm{H}_{2} \mathrm{O}$

Electrólise do $\mathrm{Cl}^{-}$:

$2 \mathrm{Cl}^{-} \rightarrow \mathrm{Cl}_{2}+2 e^{-}$

$2 \mathrm{ClO}_{2}^{-}+\mathrm{Cl}_{2} \rightarrow 2 \mathrm{ClO}_{2}+2 \mathrm{Cl}^{-}$

Quando se usa um sistema de purga gasosa para transferir o dióxido de cloro do ânodo para o tanque de armazenamento, os operadores devem estar alertados de que o ácido e possivelmente - $\mathrm{Cl}_{2}$ podem ser nebulizados ou misturados juntamente no tanque de armazenamento. Por outro lado, devem estar alertados para que, a eficiência e durabilidade da célula electroquímica dependerá da sua limpeza periódica, de forma a remover-Ihe as impurezas da superfície dos eléctrodos.

\subsection{Eficiência da conversão}

Os geradores de dióxido de cloro são programados de forma a obterem a máxima produção (rendimento) de dióxido de cloro, minimizando por outro lado a formação de cloro livre ou outros compostos oxidantes residuais. Geralmente o rendimento destes geradores é superior a $95 \%$. Por outro lado, o excesso de cloro deve ser inferior a $2 \%(\mathrm{~m} / \mathrm{m})$ no efluente do gerador.

O rendimento do gerador é definido pela seguinte expressão $[5,6]$ :

\section{$\%$ Conversão =}

'= $\frac{\left[\mathrm{ClO}_{2}\right]}{\left[\mathrm{ClO}_{2}\right]+\left[\mathrm{ClO}_{2}{ }^{-}\right]+\frac{67,45}{83,45}\left[\mathrm{ClO}_{3}^{-}\right]} \times 100$

Onde:

$$
\left[\mathrm{ClO}_{2}\right]=\begin{aligned}
& \text { Concentração em dióxi- } \\
& \text { do de cloro, } \mathrm{mg} / \mathrm{L} \text {. }
\end{aligned}
$$

$$
\begin{aligned}
& {\left[\mathrm{ClO}_{2}{ }^{-}\right]=} \begin{array}{l}
\text { Concentração em ião } \\
\text { clorito, } \mathrm{mg} / \mathrm{L} .
\end{array} \\
& {\left[\mathrm{ClO}_{3}{ }^{-}\right]=} \begin{array}{l}
\text { Concentração em ião } \\
\text { clorato, mg/L. }
\end{array} \\
&\left(\frac{67,45}{83,45}\right)=\begin{array}{l}
\text { Razão das massas } \\
\text { moleculares dos iões } \\
\text { clorito e clorato. }
\end{array}
\end{aligned}
$$

Este cálculo necessita da determinação individual de todas as espécies oxi-cloradas. No entanto, esta fórmula ignora a presença de cloro residual livre $\left(\mathrm{Cl}_{2}\right.$, $\mathrm{HOCl}, \mathrm{OCl}^{-}$) e ião perclorato.

\subsection{Pureza do dióxido de cloro}

A pureza refere-se à presença de impurezas produzidas ou transportadas através do sistema durante a produção do dióxido de cloro ou à presença de impurezas na solução de dióxido de cloro.

A expressão seguinte (baseada na relação de massas) representa, através de uma equação simples, o cálculo da pureza de dióxido de cloro produzido numa grande variedade de geradores de dióxido de cloro $[5,6]$.

\section{Pureza $(\%)=$}

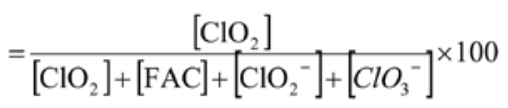

O FAC representa o excesso de cloro no efluente do gerador, assim como as espécies relacionadas $\mathrm{com} \mathrm{o} \mathrm{ClO}_{2}{ }^{-}$e é expresso através da seguinte expressão $[5,6]$ :

$F A C=$ Excesso $\mathrm{deCl}_{2}(\%)=$

$=\frac{\left[\mathrm{Cl}_{2}\right]}{\left(\left[\mathrm{ClO}_{2}\right]+\left[\mathrm{ClO}_{2}^{-}\right]+\frac{67,45}{83,45}\left[\mathrm{ClO}_{3}^{-}\right]\right) \times \frac{70,91}{2 \times 67,45}} \times 100$

Onde:

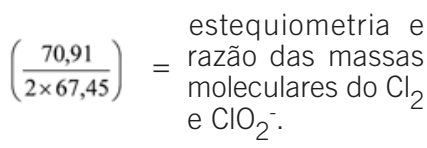

\subsection{Geradores comerciais de dióxido de cloro}

A Tabela 4 apresenta de forma resumida as reacções e as principais características dos geradores comerciais de dióxido de cloro. 


\subsection{Acção do dióxido de cloro e pontos de aplicação}

A eficácia da desinfecção pode ser avaliada através da determinação do valor de $\mathbf{C t}$ (mg.min/L) a uma determinada temperatura, o qual representa a concentração (C, mg/L) e o tempo de contacto (t, minutos) do desinfectante a uma dada temperatura, necessário para inactivar uma determinada percentagem de microrganismos.
O cálculo dos valores de $\mathbf{C t}$ para o dióxido de cloro é semelhante ao dos outros desinfectantes, isto é, determina-se a concentração de desinfectante residual e o tempo de contacto efectivo. $\mathrm{Na}$ prática, verificou-se que devido à natureza volátil do gás, o dióxido de cloro actua extremamente bem nos reactores de fluxo assim como nas condutas de distribuição. Pode ser removido das soluções aquosas diluídas por arejamento turbulento nos tanques de mistura rá- pida ou através da purga nas bacias de recarbonatação. Devem ser incluídos pontos de amostragem amplos de forma a permitir uma monitorização apertada das concentrações de desinfectante residual. É do conhecimento geral que o dióxido de cloro é destruído pela radiação ultravioleta nas bacias expostas à luz. Deste modo, se é esperado este tipo de exposição, o desenho das bacias deve apresentar formas de protecção.

Tabela 4 Geradores comerciais de dióxido de cloro

\begin{tabular}{|c|c|c|}
\hline Tipo & Reacções principais & Atributos especiais \\
\hline $\begin{array}{l}\text { Ácido-Clorito } \\
\text { (Activação ácida) }\end{array}$ & $\begin{aligned} & 4 \mathrm{HCl}+5 \mathrm{NaClO}_{2} \rightarrow 4 \mathrm{ClO}_{2}(\mathrm{aq})+\mathrm{ClO}_{3}^{-} \\
& \text {- } \mathrm{pH} \text { baixo } \\
& \text { - Possível formação } \mathrm{ClO}_{3}^{-} \\
& \text {- Velocidade de reacção lenta }\end{aligned}$ & Máximo rendimento a 80\% eficiência. \\
\hline Cloro aquoso-Clorito & $\begin{array}{l}\mathrm{Cl}_{2}+\mathrm{H}_{2} \mathrm{O} \rightarrow[\mathrm{HOCl} / \mathrm{HCl}] \\
{[\mathrm{HOCl} / \mathrm{HCl}]+\mathrm{NaClO}_{2} \rightarrow} \\
\rightarrow \mathrm{ClO}_{2}(\mathrm{~g})+\mathrm{H}^{-} \mathrm{OCl}^{-}+\mathrm{NaOH}+\mathrm{ClO}_{3}^{-} \\
\text {- } \mathrm{pH} \text { baixo } \\
\text { - Possível formação } \mathrm{ClO}_{3}^{-} \\
\text {- Velocidade de reacção } \\
\text { relativamente lenta }\end{array}$ & $\begin{array}{l}\text { Excesso de } \mathrm{Cl}_{2} \text { ou ácido para neutralizar o } \mathrm{NaOH} \text {. } \\
\text { Elevada conversão com taxa de rendimento de } 80 \text { - } \\
92 \% \text {. } \\
\text { Efluente mais corrosivo inerente aos valores baixos } \\
\text { de } \mathrm{pH}(\sim 2,8-3,5) \text {. } \\
\text { Três sistemas de bombas para a câmara de } \\
\text { reacção: } \mathrm{HCl} \text {, hipoclorito, clorito e água de diluição. }\end{array}$ \\
\hline $\begin{array}{l}\text { Cloro aquoso reciclado ou } \\
\text { "French loop" } \\
\text { (Solução saturada de } \mathrm{Cl}_{2} \\
\text { via um loop de recirculação } \\
\text { antes de haver mistura com } \\
\text { a solução de clorito). }\end{array}$ & $\begin{array}{l}2 \mathrm{HOCl}+2 \mathrm{NaClO}_{2} \rightarrow 2 \mathrm{ClO}_{2}+\mathrm{Cl}_{2}+ \\
+2 \mathrm{NaOH} \\
\text { - } \mathrm{Necessita} \mathrm{de} \mathrm{um} \mathrm{excesso} \mathrm{de} \\
\mathrm{Cl}_{2} \text { ou HCl para neutralizar o } \\
\mathrm{NaOH} \text { formado. }\end{array}$ & $\begin{array}{l}\text { Para a sua eficiência máxima requer uma } \\
\text { concentração de clorito de aproximadamente } \sim 3 g / L \text {. } \\
\text { O rendimento é de 92-98\% com um excesso de } \\
\text { cloro de } \sim 10 \% \text {. } \\
\text { Muito corrosivo para as bombas; requer calibração. } \\
\text { Após mistura necessita de um tanque de } \\
\text { maturação. }\end{array}$ \\
\hline
\end{tabular}

Cloro gasoso-Clorito $\left(\mathrm{Cl}_{2}\right.$ gasoso e solução de $\mathrm{NaClO}_{2}$ a $25 \%$; injectados para uma câmara de reacção).

$$
\begin{aligned}
& \mathrm{Cl}_{2}(\mathrm{~g})+\mathrm{NaClO}_{2}(\mathrm{aq}) \rightarrow \mathrm{ClO}_{2}(\mathrm{aq}) \\
& \text { - } \mathrm{pH} \text { neutro } \\
& \text { - Reacção rápida }
\end{aligned}
$$

Efluente com $\mathrm{pH}$ próximo da neutralidade. Não necessita de excesso de $\mathrm{Cl}_{2}$. $\mathrm{O}$ rendimento é de 95 $99 \%$ com um excesso de cloro inferior a $2 \%$.

Cloro gasoso-Matriz de clorito de sódio

$$
\mathrm{Cl}_{2}(\mathrm{~g})+\mathrm{NaClO}_{2}(\mathrm{~s}) \rightarrow \mathrm{ClO}_{2}(\mathrm{~g})+\mathrm{NaCl}
$$

$\left(\mathrm{Cl}_{2}\right.$ gasoso humidificado é bombeado através de uma matriz estável contendo clorito de sódio sólido).
- Velocidade de reacção rápida

- Tecnologia nova
$\mathrm{O} \mathrm{Cl}_{2}$ gasoso diluído com $\mathrm{N}_{2}$ ou ar filtrado produz $\sim 8 \%$ de $\mathrm{ClO}_{2}$ gasoso. Rendimentos $>99 \%$.

\section{Electroquímico}

(Geração em contínuo de $\mathrm{ClO}_{2}$ a partir de uma solução a $25 \%$ de clorito de sódio reciclada através de uma célula de electrólito).

$$
\mathrm{NaClO}_{2}(\mathrm{aq}) \rightarrow \mathrm{ClO}_{2}(\mathrm{aq})+\mathrm{e}^{-}
$$

- Tecnologia nova
Corrente de água morna em contra-corrente aceita o dióxido de cloro gasoso produzido na célula o qual atravessa uma membrana permeável ao gás.
$2 \mathrm{NaClO}_{3}+\mathrm{H}_{2} \mathrm{O}_{2}+\mathrm{H}_{2} \mathrm{SO}_{4} \rightarrow 2 \mathrm{ClO}_{2}+\mathrm{O}_{2}+$
$+\mathrm{NaSO}_{4}+\mathrm{H}_{2} \mathrm{O}$

Ácido/Peróxido/Cloreto
- Velocidade de reacção rápida

- Tecnologia nova
Usa $\mathrm{H}_{2} \mathrm{O}_{2}$ e $\mathrm{H}_{2} \mathrm{SO}_{4}$ concentrados. $\mathrm{pH}$ baixo. 


\subsubsection{Desinfecção}

Antes de se seleccionar o dióxido de cloro como desinfectante deve ser determinada a carência em oxidante da água a tratar. Idealmente, este estudo deve considerar as variações sazonais na qualidade da água, temperatura e pontos de aplicação. O MRDL (Maximum Recommended Dose Level) para o dióxido de cloro é 0,8 mg/L e o MCL (Maximum Concentration Level) para o clorito é de 1,0 mg/L [2,9]. Isto significa que se a carência em oxidante for superior a 1,4 mg/L, o dióxido de cloro não pode ser usado como desinfectante porque a razão dos iões clorito/clorato pode exceder o nível máximo permitido, a não ser que os subprodutos inorgânicos (e.g., clorito) sejam subsequentemente removidos.

As doses típicas de dióxido de cloro usadas na desinfecção da água de consumo humano variam entre 0,07 e 2 mg/L. Nas estações de tratamento que usam o dióxido de cloro, a concentração média de ião clorito e clorato variam entre 0,24 e 0,20 mg/L, respectivamente, embora o valor de referência seja de 1,0 mg/L [2,9].

\subsubsection{Controlo do sabor e do cheiro}

A fase do tratamento onde se deve aplicar o dióxido de cloro depende da qualidade da água bruta, do tipo de tratamento utilizado na estação de tratamento e de outros objectivos relacionados com a aplicação do dióxido de cloro. Nas estações de tratamento convencionais recomenda-se a utilização do dióxido de cloro próximo do fim do tratamento ou a seguir às bacias de sedimentação. Se a turvação da água bruta for baixa, por exemplo, inferior a 10 UNT (Unidades Nefelométricas de Turvação), o dióxido de cloro pode ser adicionado no início do tratamento da água. Esta utilização permite o controlo do crescimento das algas durante a floculação e nas bacias de sedimentação expostas à luz. Tal aplicação terá maior sucesso, se for efectuada durante os períodos de menor luminosidade, não só porque o crescimento das algas será menor mas também porque o dióxido de cloro será mais estável [6].

\subsubsection{Oxidação do ferro e do manganês}

O dióxido de cloro reage com as formas solúveis do ferro e do manganês para formar compostos insolúveis (precipitados) que podem ser removidos através de sedimentação ou filtração. Cerca de 1,2 mg/L de dióxido de cloro são necessários para remover 1,0 mg/L de ferro, enquanto que para remover $1,0 \mathrm{mg} / \mathrm{L}$ de manganês são necessários 2,5mg/L de dióxido de cloro. Para concentrações elevadas de ferro e manganês, a aplicação do dióxido de cloro está limitada à formação de 1,0 mg/L dos iões clorito/ clorato como subprodutos da desinfecção. O ião ferroso pode ser adicionado antes do processo de coagulação convencional de forma a reduzir o ião clorito (a ião cloreto) e aumentar a eficácia do processo de floculação na globalidade [6].

\subsection{Inactivação dos microrganismos patogénicos e eficácia da desinfecção}

O dióxido de cloro é um oxidante forte e um desinfectante. Os mecanismos de desinfecção não são bem conhecidos mas actuam sobre uma grande variedade de microrganismos [1,3].

Para baixas concentrações de dióxido de cloro, nomeadamente nas concentrações utilizadas no tratamento das águas para consumo humano, não foram observados grandes danos físicos nas células bacterianas ou nas cápsulas virais. No entanto, os estudos têm-se centrado nos dois mecanismos mais plausíveis que permitem a inactivação dos microrganismos: reacção química específica entre o dióxido de cloro e as biomoléculas e acção do dióxido de cloro sobre as funções fisiológicas dos microrganismos.

De acordo com o primeiro mecanismo de desinfecção, o dióxido de cloro reage com os aminoácidos cisteína, triptofano e tirosina, mas não reage com o ácido ribonucleico viral (RNA) [10]. Nesta investigação, conclui-se que o dióxido de cloro inactiva os vírus devido à alteração proteica da cápsula viral. No entanto, o dióxido de cloro reage com o poliovírus RNA e impede a síntese de RNA [11-13]. Também tem sido demonstrado que o dióxido de cloro reage com os ácidos gordos livres [14]. Neste momento, não está bem definido qual o processo primário de inactivação dos microrganismos pelo dióxido de cloro, se devido à actuação nas estruturas periféricas se à sua actuação sobre os ácidos nucleicos. Talvez as reacções em ambas as regiões contribuam para a inactivação dos microrganismos patogénicos.

O segundo tipo de mecanismo de desinfecção centra-se no efeito do dióxido de cloro nas funções fisiológicas. Tem sido sugerido que o primeiro mecanismo de inactivação seja a interrupção da síntese proteica [15]. Contudo, estudos posteriores revelaram que o mecanismo primário de inactivação não é a inibição da síntese proteica mas sim a alteração da permeabilidade da membrana celular [16]. Os resultados deste estudo foram confirmar os resultados já obtidos por Olivieri [12] e Ghandbari [14], os quais verificaram que as proteínas e lípidos da membrana eram suficientemente alterados pelo dióxido de cloro, devido a um aumento da permeabilidade da membrana.

Têm sido realizados vários estudos para avaliar o efeito do $\mathrm{pH}$, temperatura e matéria em suspensão na eficácia do dióxido de cloro como desinfectante. Apresenta-se de seguida, de forma muito resumida, a influência destes três factores na inactivação dos microrganismos patogénicos.

$\mathrm{O}$ pH tem uma influência muito menor na inactivação dos vírus e quistos com o dióxido de cloro do que com o cloro, para valores de $\mathrm{pH}$ entre 6 e 8,5. Contrariamente ao que acontece com o cloro, a inactivação do poliovírus / e dos quistos da Naegleria gruberi [6] pelo dióxido de cloro aumenta com o pH. Os resultados dos estudos relativos à inactivação da E. coli não são conclusivos. Embora hajam estudos antigos que demonstrem que a inactivação pelo dióxido de cloro aumenta com o aumento do $\mathrm{pH}$, estudos mais recentes demonstraram que a actividade bactericida do dióxido de cloro não é afectada para valores de $\mathrm{pH}$ entre 6,0 e 10 [6]. Um estudo com o Cryptosporidium revelou que a inactivação dos ooquistos pelo dióxido de cloro é mais rápida a pH 8,0 do que a pH 6,0. Para um valor de $\mathbf{C t}$ semelhante, o nível de inactivação a pH 8,0 é aproximada- 
Tabela 5 Valores de Ct (mg.min/L) para $99 \%$ de inactivação a $5^{\circ} \mathrm{C}[1]$

\begin{tabular}{|c|c|c|c|c|}
\hline \multirow[t]{2}{*}{ Organismo } & \multicolumn{4}{|c|}{ Desinfectante } \\
\hline & $\begin{array}{l}\text { Cloro livre } \\
\mathrm{pH}=6-7\end{array}$ & $\begin{array}{l}\text { Cloraminas } \\
\mathrm{pH}=8-9\end{array}$ & $\begin{array}{l}\text { Dióxido de cloro } \\
\qquad \mathrm{pH}=6-7\end{array}$ & $\begin{array}{l}\text { Ozono } \\
\mathrm{pH}=6-7\end{array}$ \\
\hline E. coli & $0,034-0,05$ & $95-180$ & $0,4-0,75$ & 0,02 \\
\hline Poliovírus tipo 1 & $1,1-2,5$ & $768-3740$ & $0,2-6,7$ & $0,1-0,2$ \\
\hline Vírus Hepatite A & 1,8 & ca 590 & 1,7 & - \\
\hline Rotavírus & $0,01-0,05$ & $3810-6480$ & $0,2-2,1$ & $0,006-0,06$ \\
\hline Giardia lamblia, quistos & $47->150$ & - & - & $0,5-0,6$ \\
\hline Giardia muris, quistos & $30-630$ & - & $7,2-18,5$ & $1,8-2,0$ \\
\hline Cryptosporidium parvum, oocistos & - & - & $6,5-8,9$ & $<3,3-6,4$ \\
\hline $\begin{array}{l}\text { Oocistos de Cryptosporidium } \\
\text { (fezes humanas) }\end{array}$ & $7,7 \times 10^{6}-8,7 \times 10^{6}$ & - & - & - \\
\hline
\end{tabular}

mente o dobro do obtido a pH 6,0 [17]. Outro estudo revelou que a eficácia do dióxido de cloro para a inactivação dos quistos da Giardia aumenta com o aumento do $\mathrm{pH}$. Este efeito pode ser explicado através das alterações na estrutura química e física dos quistos da Giardia pelo aumento do $\mathrm{pH}$ e não pela alteração da actividade do dióxido de cloro a diferentes valores de $\mathrm{pH}$. São necessários mais estudos para esclarecer a influência do pH na eficácia do dióxido de cloro $[6,18]$.

Tal como acontece com o cloro, a eficácia da desinfecção com o dióxido de cloro diminui com a diminuição da temperatura. LeChevallier [17] demonstrou que reduzindo a temperatura de $20^{\circ} \mathrm{C}$ para $10^{\circ} \mathrm{C}$ diminuía a eficácia da inactivação do Cryptosporidium pelo dióxido de cloro em cerca de $40 \%$ e que estes resultados são semelhantes aos obtidos com a Giardia e com os vírus.

A matéria em suspensão e a agregação dos microrganismos patogénicos afectam a eficácia da desinfecção pelo dióxido de cloro. A protecção contra a inactivação pelo dióxido de cloro foi determinada avaliando a acção sobre amostras contendo bentonite como padrão de turvação: a protecção foi de $11 \%$ para amostras com uma turvação $\leq 5$ UNT e de $25 \%$ para amostras com uma turvação entre 5 e 17 UNT [6].

Desde 1944 que se tem investigado a eficiência da acção germicida do dióxido de cloro aplicado no tratamento das águas de consumo. Normalmente esta comparação é feita com a acção do cloro e do ozono. O dióxido de cloro é um desinfectante mais eficaz que o cloro mas menos eficaz que o ozono (Tabela 5).

Por estes dados, podemos afirmar, que o desinfectante mais eficaz é o ozono, na gama de $\mathrm{pH}$ 6-7.

É necessário referir que os protozoários são mais resistentes à desinfecção do que os restantes microrganismos testados, mas o ozono continua a ser o agente desinfectante mais eficaz mesmo nestes casos.

\section{Métodos analíticos}

O Standard Methods [6,19] propõe numerosos métodos analíticos para a medição das espécies cloradas que acompanham a produção do dióxido de cloro. Existe uma certa confusão em torno destes métodos assim como nos testes de campo disponíveis para o efeito. Devido à falta de especificidade de alguns métodos, nomeadamente dos métodos de oxidação (e.g., iodométrico, dietil-p-fenilenodiamina), eles apresentam elevada interferência.

A determinação exacta do dióxido de cloro e dos respectivos subprodutos clorados requer uma metodologia analítica com uma maior selectividade e precisão. Dos vários métodos existentes, foram largamente usados três métodos colorimétricos para determinar a concentração residual em dióxido de cloro: método da Lissamina Green B (LGB) [20], método de Amarante [21] e método do vermelho de clorofenol. Cada um destes métodos é capaz de determinar o dióxido de cloro em concentrações na ordem dos 0,1 mg/L. O método colorimétrico da DPD (dietil-p-fenilenodiamina) não é adequado à determi- nação do dióxido de cloro [5] porque as espécies de DPD oxidadas que são quantificadas a $515 \mathrm{~nm}$ podem continuar a reagir com o dióxido de cloro, dando origem a um composto incolor (i.e., há perda da cor já formada). Na água tratada, além do dióxido de cloro temos também o ião clorito e o cloro residual livre como desinfectante residual. Sendo assim, em cada amostra de água (i.e., efluente do gerador de dióxido de cloro, água à saída da estação de tratamento e água da rede de distribuição) tem que se determinar o ião clorito e a interferência do cloro. O método da Lissamin Green B e o método de Amarante utilizam um sistema tampão de amónia/ cloreto de amónia que elimina a potencial interferência do cloro e é um dos métodos a escolher. Deste modo, o ião clorito não é interferente em nenhum destes métodos. Contrariamente a estes dois métodos, o método do vermelho de clorofenol sofre interferência do clorito e do cloro residual, embora a interferência do cloro residual possa ser eliminada através da adição de ácido oxálico. No entanto, não nos podemos esquecer que, mesmo estes métodos relativamente selectivos podem sofrer interferência das multi-espécies cloradas que podem ocorrer nas soluções de dióxido de cloro, pelo que os métodos deverão descriminar/distinguir o dióxido de cloro dos restantes compostos. Um dos métodos consiste na análise do dióxido de cloro após difusão deste através de uma membrana selectiva [22].

Sendo assim, o método de eleição para a determinação dos subprodutos clorados em concentrações na ordem dos 0,1-1 mg/L é a cromatografia iónica. 


\section{Referências}

[1] C. M. M. Almeida, "Especiação Orgânica em Águas para Consumo Humano: Fenol, Benzeno e Compostos Derivados", Dissertação apresentada à Faculdade de Farmácia da Universidade de Lisboa para a obtenção do grau de Doutor, 2001.

[2] WHO (World Health Organization), "Guidelines for Drinking Water Quality", Third Edition, 2004.

[3] N. M. G. Simões, "Fenol e Clorofenóis em Águas para Consumo Humano: Optimização do Método de Análise por SPME-GC/MS", Dissertação apresentada à Faculdade de Farmácia da Universidade de Lisboa para a obtenção do grau de Mestre em Controlo da Qualidade e Toxicologia dos Alimentos, 2004.

[4] Hemetério Monteiro, "Desinfectantes e Sub-produtos da Desinfecção". Águas \& Resíduos (1996)18-20.

[5] G. Gordon, "Is All Chlorine Dioxide Created Equal?", Journal of American Water Works Association, April, (2001)163174.

[6] USEPA (U.S. Environmental Protection Agency), "Alternative Disinfectants and Oxidants EPA Guidance Manual, Section 4: Chlorine Dioxide". EPA 815-R-99-014 (Apr 1999).

[7] AWWA (American Water Works Association), Water Quality and Treatment, fourth edition, McGraw-Hill, Inc., New York, 1990.

[8] G. Gordon, B. Slootmackers, S. Tachiyashiki, D. W. Wood, "Minimizing Chlorite
Ion and Chlorate Ion in Water Treated with Chlorine Dioxide", Journal of American Water Works Association 82(4) (1990)160-165.

[9] EPA, 2004. US EPA List of Drinking Water Contaminants \& MCLs: http://www.epa. gov/safewater/mcl.html.

[10] C. I. Noss, W. H. Dennis, V. P. Olivieri, "Reactivity of Chlorine Dioxide with Nucleic Acids and Proteins". Water Chlorination: Environmental Impact and Health Effects. R.L.Jolley (editors), Lewis Publishers, Chelsea, MI., 1983.

[11] M. E. Alvarez, R. T. O'Brien, "Mechanism of Inactivation of Poliovirus by Chlorine Dioxide and lodine", Appl. Envir. Microbiol. 44 (1982)1064.

[12] V. P. Olivieri, "Mode of Action of Chlorine Dioxide on Selected Viruses", Water Chlorination: Environmental Impact and Health Effects. R.L. Jolley (editors), Lewis Publishers, Chelsea, MI., 1985.

[13] Y. S. R. Chen, O. J. Sproul, A. J. Rubin, "Inactivation of Naegleria gruberi cysts by Chlorine Dioxide", Water Res. 19(6) (1985) 783.

[14] E. H. Ghandbari, "Reactions of Chlorine and Chlorine Dioxide with Free Fatty Acids, Fatty Acids Esters, and Triglycerides". Water Chlorination: Environmental Impact and Health Effects. R.L. Jolley (editors), Lewis Publishers, Chelsea, MI, 1983.

[15] M. A. Bernarde, "Kinetics and Mechanism of Bacterial Disinfection by Chlorine Dioxide", J. Appl.Microbiol.15(2) (1967) 257.
[16] E. Aieta, J. D. Berg, "A Review of Chlorine Dioxide in Drinking Water Treatment", Journal of American Water Works Association 78(6)(1986)62-72.

[17] W. LeChevallier, W. D. Norton, T. B. Atherholf, "Chlorine Dioxide for Control of Cryptosporidium and Disinfection Byproducts". Proceedings of the American Water Works Association Water Quality Technology Conference, Boston, MA, November 17-21, American Water Works Association, 1997.

[18] L. R. J. Liyanage, "Effects of Aqueous Chlorine and Oxychlorine Compounds on Cryptosporidium Parvum Oocysts", Environ. Sci. \& Tech. 31(7) (1997) 1992-1994.

[19] L. S Clesceri, A. E. Greenberg, A. D. Eaton, Editors, Standard Methods for the Examination of Water and Wastewater. American Public Health Association, Washington, DC, USA, 20th Edn, 1995.

[20] B. Chiswell, K. O’Halloran, "Use of Lissamine Green B as a Spectrophotometric Reagent for the Determinattion of Low Levels of Chlorine Dioxide", Analyst 116 (1991) 657

[21] G. E. Emmert, D. E. Coutant, D. L. Sweetin, G. Gordon, B. Bubnis, "Studies of Selectivity in the Amaranth Method for Chlorine Dioxide", Talanta 51(2000) 879-888.

[22] D. A. Hollowell, G. E. Pacey, G. Gordon, "Selective Determination of Chlorine Dioxide Using Gas Difusion Flow Injection Analysis", Anal. Chem. 57 (1985) 2851.

\section{Actualidades Científicas}

Um dos gigantes dos edulcorantes artificiais nos Estados Unidos, a Merisant - que comercializa aspartame sob as marcas comerciais Equal e NutraSweet - o equivalente em Portugal será o Canderel - processou o outro gigante do mercado, a McNeil Nutritionals, que comercializa sucralose com o nome Splenda - em Portugal a sucralose é comercializada pela Linea. Em causa está a campanha publi-

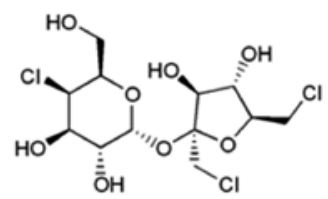

sucralose citária desta última que inclui a frase «feito de acúcar, pelo que sabe a açúcar».

A sucralose, ou mais concretamente a 1,6 - dicloro- 1,6 - didesoxi - B-D-fructofuranosil-4-cloro-4-desoxi-B-D-galactopiranosídeo, é um derivado da sacarose, o acúcar comercial, em que três grupos hidroxilo foram substituídos por cloro.

Quimicamente, o aspartame é N-L-alfa-aspartil-L-fenilalanina 1-metilester pelo que a Merisant não pode usar o equivalente na sua propaganda porque não teria o mesmo efeito dizer que o aspartame é feito de ácido aspártico e fenilalanina.

Mas no cerne da questão está o facto de que o aspartame, que já foi lider incontestado do mercado dos adoçantes artificiais, ter vindo a perder terreno para a sucralose, que actualmente detém $62 \%$ do mercado norte-americano. 0 julgamento da controversa frase, que segundo a Merisant induz os compradores a pensar que sucralose é mais «natural» que os adoçantes concorrentes, contará com a presença de químicos que defenderão a causa de ambos os lados. Isto é, num inédito nos Estados Unidos, as testemunhas de acusação e de defesa serão principalmente químicos!

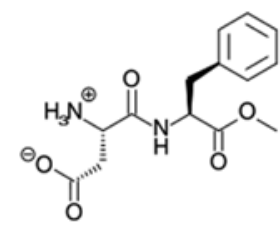

aspartame 


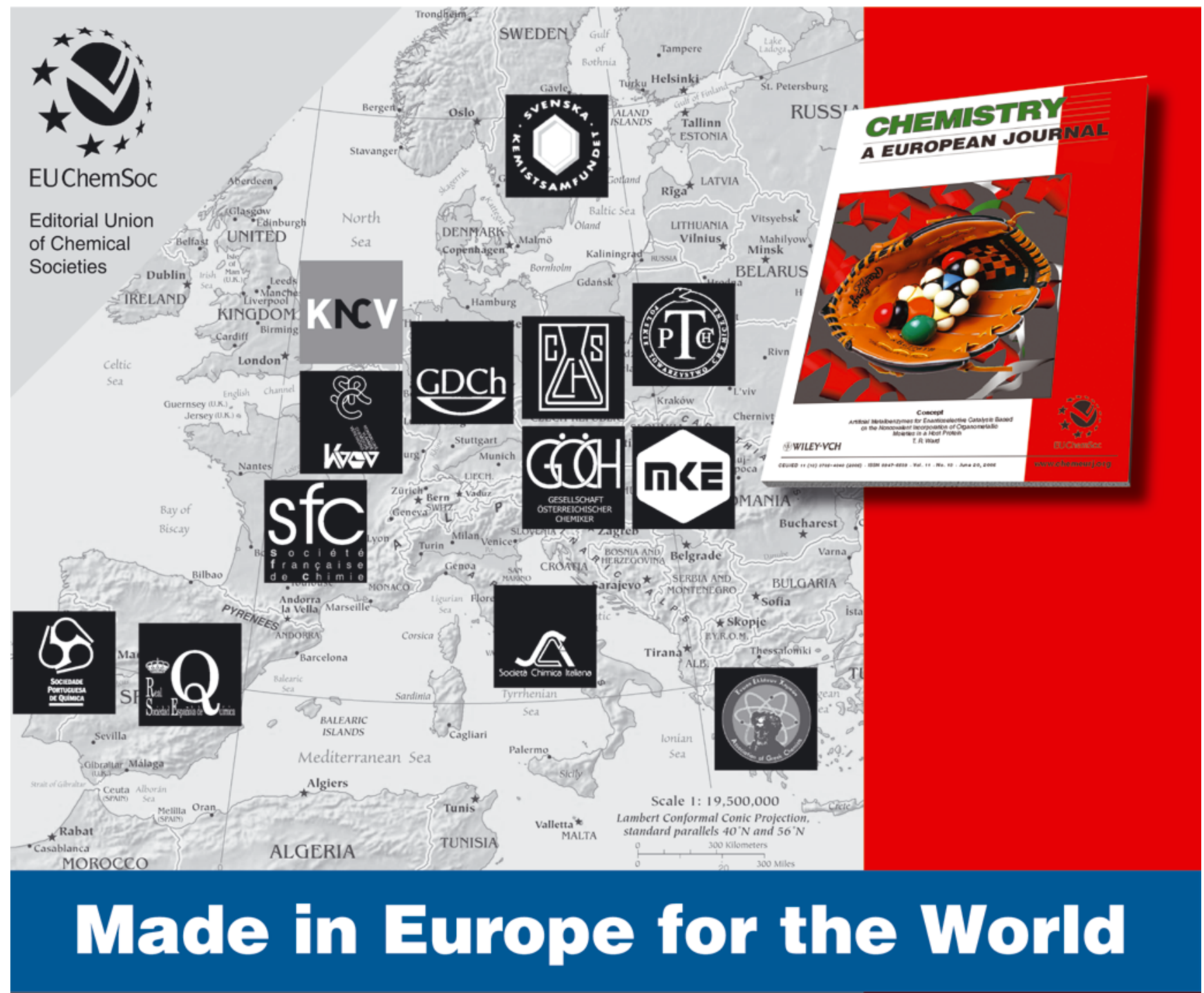

Top quality contributions covering all areas of chemistry and related fields

Increased Frequency: $\mathbf{3 6}$ issues in $\mathbf{2 0 0 6}$

Y ISI Impact Factor (2004): 4.517

A truly international journal

Owned and supported by 14 European chemical societies

All manuscripts are peer-reviewed

Short publication times guaranteed by EarlyView

Rapid processing of manuscripts through manuscriptXpress

manuscript) press

World renowned international Editorial Board

$\checkmark$ The fastest growing full-paper journal

For further information

and to subscribe

please send an E-mail to:

subinfo@wiley.com

(USA/Canada)

service@wiley-vch.de

(Germany/Austria/Switzerland)

cs-journals@wiley-co.uk

(all other areas)

\section{Subscribe now: www.chemeurj-org}

